\title{
FORMULATION AND CHARACTERIZATION OF CYCLODEXTRIN BASED CURCUMIN LOADED NANOSPONGE
}

\author{
ANUP M. AKARTE*, PRAKASH H. PATIL \\ Department of Pharmaceutics, K. V. P. S.'s Institute of Pharmaceutical Education, Boradi, India \\ *Email: anup_akarte@rediffmail.com
}

Received: 29 Jul 2021, Revised and Accepted: 11 Nov 2021

\begin{abstract}
Objective: The aim of proposed work is to develop and screen cyclodextrin based Nanosponge loaded with poorly soluble anticancer drug and to optimize most suitable Nanosystem with increased solubility and dissolution rate.

Methods: Cyclodextrinnanosponge (CDNS) was prepared using pyromelliticdianhydride as a crosslinker for beta cyclodextrin monomer. Cyclodextrinnanosponge and curcumin were taken in $1: 1 \mathrm{w} / \mathrm{w}$ proportion. The resultant curcumin loaded nanosponges were dried at $50 \pm 0.5{ }^{\circ} \mathrm{C}$ for $24 \mathrm{~h}$.

Results: The absorbance maxima for Curcumin was seen at $424.0 \mathrm{~nm}$ and for cyclodextrin was seen at $290.0 \mathrm{~nm}$, The average melting point of pure drug is $181^{\circ} \mathrm{C}$ which is complies with Stander melting point of drug and the aspect ratio of the nanosponge was found 1.037. Zeta potential noticed for CUR-CD-NS were more negative contrasted with separate plain CUR20.1 \pm 1.57 ) demonstrating solidness of the nanodispersion. Curcumin release from CUR-CDNS was upgraded to very nearly 10 folds toward the finish of 8 hour. Treatment with a combination of CUR-CDNS at $1: 1$ and $1: 3$ ratios resulted in an $\mathrm{IC}_{50}$ value was found $14.98 \mu \mathrm{g} / \mathrm{ml}$.
\end{abstract}

Conclusion: In vitro cytotoxicity study and combination index analysis showed the synergistic effect of CUR-CDNS against MCF-7 cells. The present study reveals that the combination of curcumin results in higher cytotoxicity against breast cancer cells.

Keywords: Nanosponge, Cyclodextrin, Cancer, Curcumin and Nanosystem

(C) 2022 The Authors. Published by Innovare Academic Sciences Pvt Ltd. This is an open access article under the CC BY license (https://creativecommons.org/licenses/by/4.0/) DOI: https://dx.doi.org/10.22159/ijap.2022v14i1.47788. Journal homepage: https://innovareacademics.in/journals/index.php/ijap

\section{INTRODUCTION}

Cancer has afflicted people for several centuries. It is because of the early research that we hold a greater knowledge of cancer today. The word Cancer is gotten from the Greek word Karakinos, for "crab." Cancer can begin anyplace in the human body, which is comprised of trillions of cells. Typically, human cells develop and gap to frame new cells as the body needs them. At the point when cells develop old or become harmed, they pass on, and new cells have their spot. At the point when malignant growth grows, nonetheless, this methodical cycle separates. As cells become an ever increasing number of strange, old or harmed cells endure when they should bite the dust, and new cells structure when they are not required. These additional phones can separate ceaselessly and may frame developments called Tumor [1].

Cancer is multi-factorial group of diseases that is normally associated with wide range of deregulated effects both at the molecular and cellular levels. The old style perspective on malignant growth etiology is that hereditary modifications harm the DNA structure and initiates transformation (adjusted grouping data) bringing about non-practical proteins that lead to illness movement. Malignant growth is an infection of the qualities. A quality is a little piece of DNA, which is the expert particle of the cell. Qualities make "proteins," which are definitive workhorses of the cells. It is these proteins that permit our bodies to complete every one of the cycles that grant us to inhale, think, move, and so forth For the duration of individuals' lives, the cells in their bodies are developing, isolating, and supplanting themselves. Numerous qualities produce proteins that are associated with controlling the cycles of cell development and division. An adjustment (change) in the DNA atom can disturb qualities and produce defective proteins. This makes the cell become strange and lose its limitations on development. The strange cell starts to separate wildly and at last structures another development known as a "Tumor" orneoplasm [2]

Curcumin, also known as diferuloylmethane, is an active component in the golden spice turmeric (Curcuma longa) and in Curcuma xanthorrhiza oil. It is a profoundly pleiotropic atom that displays antibacterial, calming, hypoglycemic, cancer prevention agent, wound-mending, and antimicrobial exercises [3-6]. Because of these properties, curcumin has been explored for the therapy and strong consideration of clinical conditions including proteinuria, bosom malignancy, numerous myeloma, discouragement, and Non-Small Cell Lung Cancer (NSCLC). In spite of demonstrated adequacy against various test models, helpless bioavailability because of helpless retention, quick digestion, and fast foundational disposal have been displayed to restrict the restorative viability of curcumin [7].

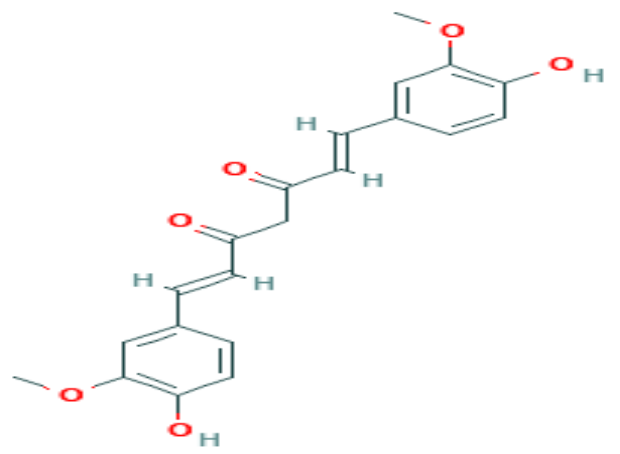

Fig. 1: Structure of curcumin

Different names have been used to refer to CDs. These include Schardinger dextrins, cycloamyloses and cycloglucans; CDs is the most common name. CDs are composed of a number of glucopyranose units attached by $\alpha$-(1-4)-linkages [8]. The glucopyranose units are designated by Greek letters to denote the number of glucose units; $\alpha$ representing 6 glucose units, $\beta$ for 7 and $\gamma$ for 8 glucose units. CDs that contain 9 to 100 glucose units are known, however, the most commonly studied CDs are those of $\alpha-, \beta$ and $\gamma$-CD. So nowadays need of the development of cyclodextrin based Nanosponge loaded with poorly soluble anticancer drug for the enhancement the solubility and dissolution profile [9-11]. 


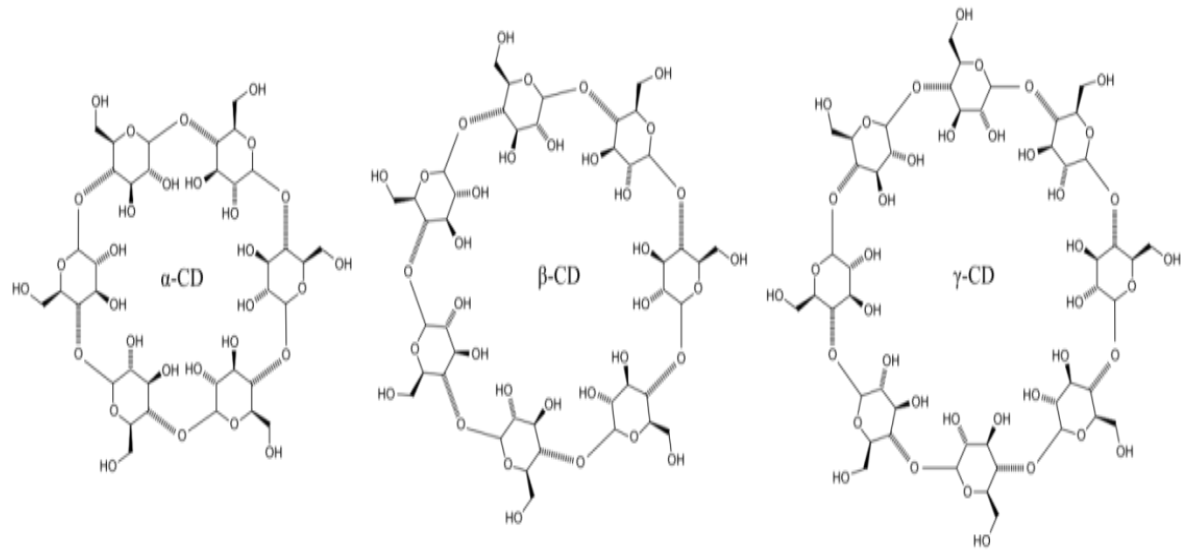

Fig. 2: Structure of cyclodextrin

\section{MATERIALS AND METHODS}

\section{Pre-formulation studies}

\section{Infrared spectroscopy study}

The medication powder of Curcumin and cyclodextrin with $\mathrm{KBr}$ were readied utilizing water powered pellet press at a pressing factor of 7 to 10 tones. FTIR was checked from $400-4000 \mathrm{~cm}^{-1}$ by utilizing perkin Elmer range GX FTIR. FTIIR study was completed exclusively for drug, record FTIR spectra of unadulterated medication and polymer [12].

\section{Determination of analytical wave length}

A standard stock arrangement of Curcumin and cyclodextrin independently in $0.1 \mathrm{~N} \mathrm{HCl}$ was readied having a focus $600 \mu \mathrm{g} / \mathrm{ml}$. A $5.0 \mathrm{ml}$ bit of stock arrangement was additionally weakened Curcumin water in a $100.0 \mathrm{ml}$ volumetric flask up to check to get last concentration $30 \mu \mathrm{g} / \mathrm{ml}$. The standard solution of Curcumin $(30$ $\mu \mathrm{g} / \mathrm{ml}$ ) was checked in the scope of $600-200 \mathrm{~nm}$. In $1.0 \mathrm{~cm}$ cell against dissolvable clear and spectra was recorded, the absorbance maxima for Curcumin was seen at $424.0 \mathrm{~nm}$ and for cyclodextrin was seen at $290.0 \mathrm{~nm}$ [13].

\section{Melting point study}

The dissolving point study was carring out Curcumin and cyclodextrin the assistance of open slim technique or differential scanning colorimetry (DSC).

\section{Standard calibration curve of curcumin and cyclodextrinin 6.8 pH buffer}

Stock arrangement of Curcumin and cyclodextrin was set up by dissolving $50 \mathrm{mg}$ of medication in $200 \mathrm{ml}$ of 6.8 phosphate support. Aliquots of $1,2,3,4,5,6 \mathrm{ml}$ (5 to $30 \mu \mathrm{g} / \mathrm{ml}$ ) were moved independently in to $50 \mathrm{ml}$ volumetric cups from the stock arrangement. Volume was changed sufficient Curcumin and cyclodextrin a similar dissolvable. Absorbance of the above arrangements was taken at $424.0 \mathrm{~nm}$ and $290.0 \mathrm{~nm}$ for Curcumin and cyclodextrin individually, against the blank. Spectra of absorbance Vs concentration was plotted [15].

\section{Particle size measurement}

Particle size analysis was carried out by malvonizer apparatus and sieve analysis method.

\section{Preparation of curcuminnanosponges}

Cyclodextrinnanosponge (CDNS) was prepared using pyromelliticdianhydride as a crosslinker for beta cyclodextrin monomer as per the previously reported procedure. Betacyclodextrin $(0.0054 \mathrm{M})$ was disintegrated in dimethylsulfoxide containing triethylamine. The arrangement was added with pyromelliticdianhydride $(0.01073 \mathrm{M})$, blended and let to respond at room temperature for $3 \mathrm{~h}$. The item was Soxhlet removed utilizing
$\left.\mathrm{CH}_{3}\right)_{2} \mathrm{CO}$ for $24 \mathrm{~h}$ and dried at $60{ }^{\circ} \mathrm{C} \pm 0.5$ for $24 \mathrm{~h}$. The pre-arranged nanosponges contain $1: 2 \mathrm{M}$ proportion of cyclodextrin and crosslinker. The system was continued utilizing a higher measure of pyromelliticdianhydride $(0.0215 \mathrm{M})$ to get ready nanosponges having a molar proportion of 1:4 (cyclodextrin: crosslinker). In view of our previous investigation, pyromelliticdianhydride cross-connected beta cyclodextrin having cyclodextrin to crosslinker molar proportion 1:2 was utilized for stacking curcumin. Cyclodextrinnanosponge and curcumin were taken in 1:1 w/w proportion. Curcumin arrangement was arranged utilizing dichloromethane. To this arrangement, nanosponge was added and dissipated under mixing to eliminate the dissolvable. The resultant curcumin loaded nanosponges were dried at $50 \pm 0.5^{\circ} \mathrm{C}$ for $24 \mathrm{~h}$. The dried items got were contracted as CUR-CDNS for curcumin loaded nanosponges [16].

\section{Characterization of $\mathrm{CD}$ based curcumin nanosponges}

\section{Surface morphology}

Scanning Electron Microscope (SEM) (Model: JSM 5200, Japan) was used to characterize surface morphology of prepared nanosponge. The examples were ready by engrossing the nano wipe on twofold size sticky tape which adhered to aluminum wound and gold covered under vacuum utilizing a falter coater. Tests were presented to vacuum for $5-10 \mathrm{~min}$. at $40 \mathrm{~mA}$ and explored at speeding up voltage of $15 \mathrm{kV}$ and $10 \mathrm{kV} 12$ [17].

\section{Transmission electron microscope (TEM)}

The surface morphology of CUR-CDNS was studied by TEM (transmission electron microscope, Technai 20 G2, FEI, The Netherlands). The fluid scattering of the example was set on the carbon-covered copper network and stained with phosphotungstic corrosive and checked with TEM at various amplifications [18].

\section{Zeta potential analysis}

Zeta potential of the nanosponge was determined by Malvern Nano Zetasizer instrument. Zeta potential of the formulation is as follows. The zeta potential study depicts stability of the nanosponge formulations which lies within desired $\mathrm{mV}$ range [19].

\section{FT-IR analysis}

The analysis of formulation was done by FT-IR (Brukner, Germany) spectrometer. Sample was scanned by FTIR under the range of 400$4000 \mathrm{~cm}^{-1}$. The spectra of formulation were interpreted to ensure the presence of drug inside the formulation [20].

\section{X-ray crystallography}

X-ray diffraction patterns of curcumin, CD nanosponge and C-CD-NS were determined using a diffractometer equipped with a rotating target X-ray tube and a wide-angle goniometer. The X-beam source was-beam tube was worked at a capability of $45 \mathrm{kV}$ and a current of $40 \mathrm{~mA}$. The scope of sweeps was performed from $10^{\circ} \mathrm{C}$ to $80^{\circ} \pm 0.5 \mathrm{C}$ at a speed of $4{ }^{\circ} \mathrm{C}$ each moment at additions of $0.05^{\circ} \mathrm{C}[21]$. 


\section{Drug content}

Curcumin content in nanosponges accurately weighed amount of nanosponge product was dissolved in methanol, sonicated, filtered, diluted suitably and analyzed using UV spectrophotometry at 424 $\mathrm{nm}$ for curcumin [22].

\section{Solubility study}

Solubility of CU, physical mixture, and CU-NS (obtained from different ratios of drug and NS) was determined by shake flask apparatus. Momentarily, overabundance of CU, actual blend, and CUNS were added to HPLC grade water in fixed glass compartments at $25{ }^{\circ} \mathrm{C}$. The examples were disturbed at $100 \mathrm{rpm}$ for $24 \mathrm{~h}$ in the shaker water shower (EQUITRON® ${ }^{\circledR} 147$, Medica Instrument Mfg. 148 Co., India), then, at that point centrifuged at $10,000 \mathrm{rpm}$ for 10 min. The supernatants were separated $(0.45 \mu \mathrm{m} 149$ PVDF needle channel, Millipore Millex-HV). The filtrate was appropriately weakened with methanol and broke down by switch stage HPLC comprising of a Waters. A C18 Luna ${ }^{\circledR}$ RP-HPLC $(250152 \mathrm{~mm} \times 4.6$ $\mathrm{mm}, 5 \mu \mathrm{m}$ ) (PhenomenexInc., CA, USA) insightful section was utilized for the assessment. The improved portable stage was made out of ammonium acetic acid derivation support $(\mathrm{pH} 4.0)$ and acetonitrile $(42: 58 \mathrm{v} / \mathrm{v})$, with $1 \mathrm{ml} / \mathrm{min}$ stream rate. Tests of $20 \mu \mathrm{l}$ were broke down for evaluation of $\mathrm{CU}$ at $424 \mathrm{~nm}$ utilizing PDA locator [23].

\section{Loading efficiency}

The loading efficiency (\%) of curcumin loaded in C-CD-NS was determined as follows: A known measure of C-CD-NS was taken and broken up in total ethanol (Analytical Reagent $99.9 \% \mathrm{v} / \mathrm{v}$ ) and the medication content was investigated utilizing UV spectrophotometer (Shimadzu UV $2101 \mathrm{PC}$ ) at $424 \mathrm{~nm}$ after fitting weakenings. The loading efficiency was calculated from the following Equation [23].

Amount of curcumin incorporated in CD nanoparticles

$$
\text { Amount of curcumin initially added } \times 100
$$

\section{Differential scanning calorimetry (DSC)}

Thermal characteristics of CU, NS, physical mixture, and the nanosponge complex of CU were analyzed using DSC (DSC 821e, Mettler-Toledo International Inc., and Switzerland). Each example (3-5 $\mathrm{mg}$ ) was warmed in a creased aluminum skillet somewhere in the range of $25 \pm 0.5^{\circ} \mathrm{C}$ and $300 \pm 0.5^{\circ} \mathrm{C}$ at a filtering pace of $20 \pm 0.5^{\circ} \mathrm{C} / \mathrm{min}$ and under a nitrogen stream of $40 \mathrm{ml} / \mathrm{min}$. Instrument was recently adjusted with void search for gold and indium for heat rate [24].

\section{Drug release study}

In vitro release study Franz diffusion cell with a diameter of $2.4 \mathrm{~cm}$ was used for the in vitro release study. The receptor compartment was added with $30 \mathrm{ml}$ arrangement containing phosphate cradled saline and methanol $(1: 1)$ and permitted to equilibrate at $32{ }^{\circ} \mathrm{C}$ utilizing a hot plate with an attractive stirrer. Receptor stage was isolated from the benefactor stage by a layer channel type $0.2 \mu \mathrm{m}$, Sartorius AG W-3400 Goettingen Germany, recently absorbed receptor liquid for $24 \mathrm{~h}$. The fluid scattering of CUR, CUR-CDNS were ready and utilized for in vitro discharge test. The benefactor compartment was then added with $5 \mathrm{ml}$ watery scattering of test. The contributor receptor interface and every one of the openings are fixed utilizing parafilm to forestall vanishing. The receptor medium was kept up with at $32{ }^{\circ} \mathrm{C}$ and blended at $200 \mathrm{rpm}$ utilizing attractive stirrer. Tests $(2 \mathrm{ml})$ were removed from the receptor stage at foreordained time periods min, supplanted with the new medium. Removed examples were reasonably weakened and examined by HPLC strategy utilizing $\mathrm{C}_{18}$ section (4.6 mm I. D x 100 $\mathrm{mm} \times 5 \mu \mathrm{m}$; Shimadzu) with the portable stage containing methanol and $0.5 \%$ acidic corrosive $(75: 25)$ at a stream pace of $0.5 \mathrm{ml} / \mathrm{min}$ $\left(\mathrm{r}^{2}-0.999,1 \mathrm{ng}\right.$ to $\left.10 \mu \mathrm{g}\right)$. The experiment was carried out in triplicate for each test sample [25].

\section{In vitro cytotoxicity test}

Cytotoxicity of curcuminnanosponge and their combination were studied in MCF-7 (human breast adenocarcinoma) cell lines. CURCDNS samples were mixed in ratios 1:3, 1:1 and 3:1 by weight and labeled as V1, V2 and V3. CUR-CDNS were labeled as C. Distinctive fixation going from $1 \mu \mathrm{g} / \mathrm{ml}$ to $125 \mu \mathrm{g} / \mathrm{ml}$ were ready for each test tests C, V1, V2, V3 and utilized for cytotoxicity test. Cell reasonability was evaluated utilizing MTT ((3-(4,5dimethyl thiazole-2yl)-2,5diphenyl tetrazolium bromide) examine strategy. Cell culture having $1.0 \times 105$ cells $/ \mathrm{ml}$ was arranged utilizing Dulbecco's changed fundamental medium containing 10\% Fetal cow-like serum (FBS). $100 \mu \mathrm{l}$ of sub refined cell suspension was added to each well of a 96 well microtiter plate, added with test tests of various fixations and hatched for $72 \mathrm{~h}$ at $37{ }^{\circ} \mathrm{C}$ in $5 \% \mathrm{CO}_{2}$ air. After brooding, each all around was added with $20 \mu \mathrm{l}$ of MTT $(2 \mathrm{mg} / \mathrm{ml})$ in MEM without phenol red and hatched for $3 \mathrm{~h}$. The supernatant medium was taken out and added with $50 \mu \mathrm{l}$ of isopropanol. The plates were perused at $540 \mathrm{~nm}$ utilizing microplateperuser. Cell feasibility is determined as the proportion of test cell absorbance to control cell absorbance and communicated in rate. Fixation needed to repress cell development by half was produced from the portion reaction bend for test tests $\mathrm{C}$, V1, V2 and V3. Clear nanosponge test was utilized as a control test. The data was analyzed by Compusyn software to compute the combination index (CI) value to evaluate the synergetic effect [26].

\section{Stability studies}

The stability study was carried out for Nano sponge formulation as per ICH guidelines. The nanosponge were placed in screw capped glass container and stored at ICH storage $\left(40{ }^{\circ} \mathrm{C} \pm 2\right.$ ${ }^{\circ} \mathrm{C} / 75 \% \mathrm{RH} \pm 5 \% \mathrm{RH}$ ) condition for a period of $60 \mathrm{~d}$. The samples were analyzed for physical appearance and for the drug content.

Table 1: ICH guidelines for stability study

\begin{tabular}{lll}
\hline Study & Storage condition & Time period \\
\hline Long term & $25^{\circ} \mathrm{C} \pm 2{ }^{\circ} \mathrm{C} / 60 \% \mathrm{RH} \pm 5 \mathrm{RH}$ & $12 \mathrm{mo}$ \\
Intermediate & $30^{\circ} \mathrm{C} \pm 2{ }^{\circ} \mathrm{C} / 65 \% \mathrm{RH} \pm 5 \% \mathrm{RH}$ & $6 \mathrm{mo}$ \\
Accelerated & $40^{\circ} \mathrm{C} \pm 2{ }^{\circ} \mathrm{C} / 75 \% \mathrm{RH} \pm 5 \% \mathrm{RH}$ & $6 \mathrm{mo}$ \\
\hline
\end{tabular}

\section{RESULTS AND DISCUSSION}

Table 2: Physical parameter

\begin{tabular}{lll}
\hline S. No. & Parameter & Result \\
\hline 1 & Color & A yellowish amorphous powder \\
2 & Odour & Characteristic \\
3 & Taste & Slight pungeant \\
\hline
\end{tabular}

A standard stock arrangement of Curcumin and cyclodextrin independently in $0.1 \mathrm{~N} \mathrm{HCl}$ was readied having a focus $600 \mu \mathrm{g} / \mathrm{ml}$. A 5.0 $\mathrm{ml}$ bit of stock arrangement was additionally weakened Curcumin water in a $100.0 \mathrm{ml}$ volumetric flask up to check to get last concentration
$30 \mu \mathrm{g} / \mathrm{ml}$. The standard arrangement of Curcumin $(30 \mu \mathrm{g} / \mathrm{ml})$ was checked in the scope of $600-200 \mathrm{~nm}$. In $1.0 \mathrm{~cm}$ cell against dissolvable clear and spectra was recorded, the absorbance maxima for Curcumin was seen at $424.0 \mathrm{~nm}$ and for cyclodextrin was seen at $290.0 \mathrm{~nm}$. 


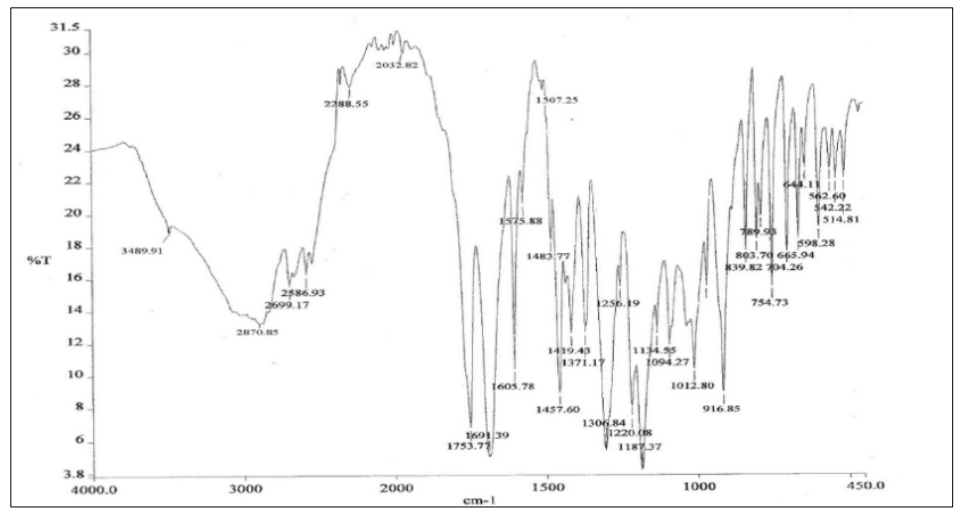

Fig. 3: FTIR spectrum of curcumin

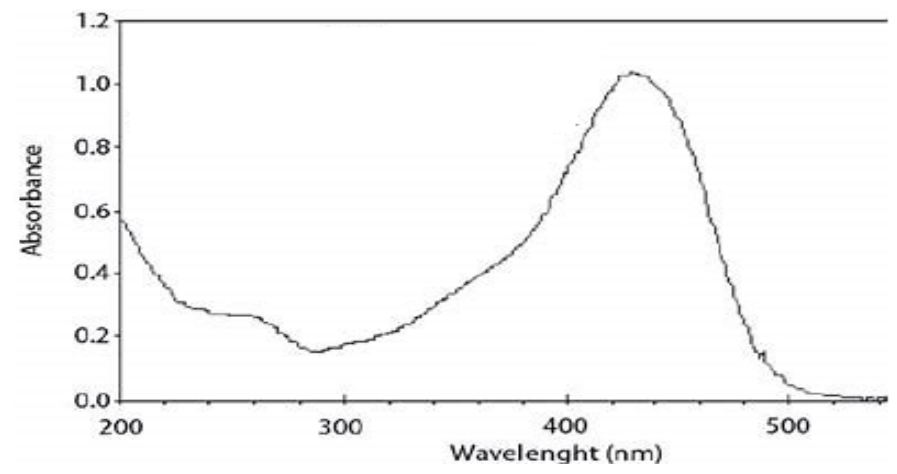

Fig. 4: UV spectrum of curcumin in 6.8 phosphate buffer

X-ray diffraction patterns of curcumin powder were determined using a diffractometer outfitted with a pivoting objective X-beam tube and a wide-point goniometer. The X-beam source was-beam tube was worked at a capability of $45 \mathrm{kV}$ and a current of $40 \pm 1.40 \mathrm{~mA}$.

\section{DSC study}

The DSC test was done on curcumin was presented below
Table 3: DSC Study of curcumin

\begin{tabular}{lll}
\hline S. No. & Stage & Temperature \\
\hline 1 & Onset & $180.26 \pm 0.5^{\circ} \mathrm{C}$ \\
2 & Peak & $181.20 \pm 0.5^{\circ} \mathrm{C}$ \\
3 & End set & $182.42 \pm 0.5^{\circ} \mathrm{C}$ \\
\hline
\end{tabular}

Where $n=3$, mean \pm SEM

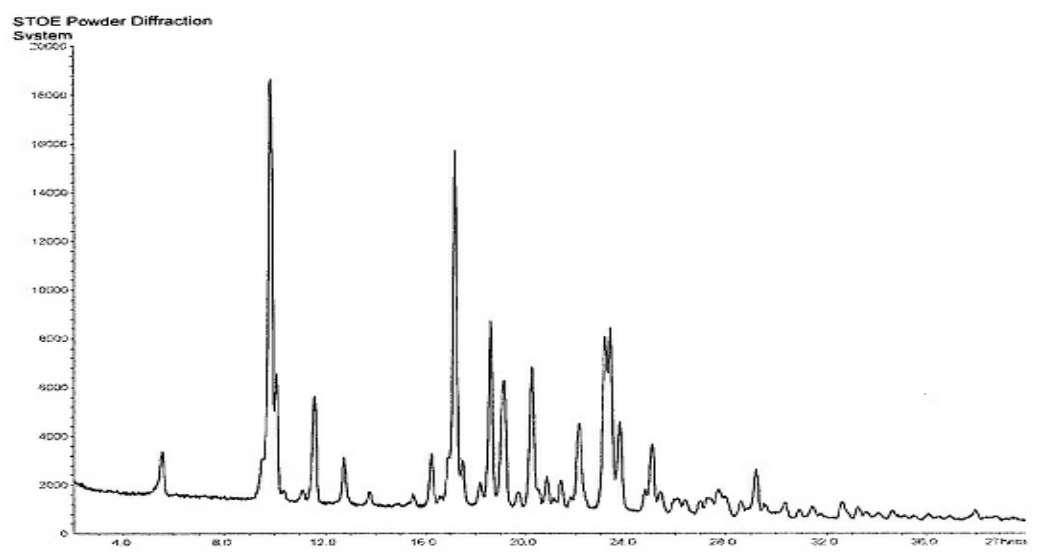

Fig. 5: X-ray powder diffraction pattern of curcuminin crystalline form

Table 4: Melting point of pure drug

\begin{tabular}{lll}
\hline S. No. & Melting point $\left({ }^{\circ} \mathbf{C}\right)$ & Average melting point $\left({ }^{\circ} \mathbf{C}\right)$ \\
\hline 1 & $182 \pm 0.5$ & 181.00 \\
2 & $180 \pm 0.5$ & \\
3 & $181 \pm 0.5$ & \\
\hline
\end{tabular}




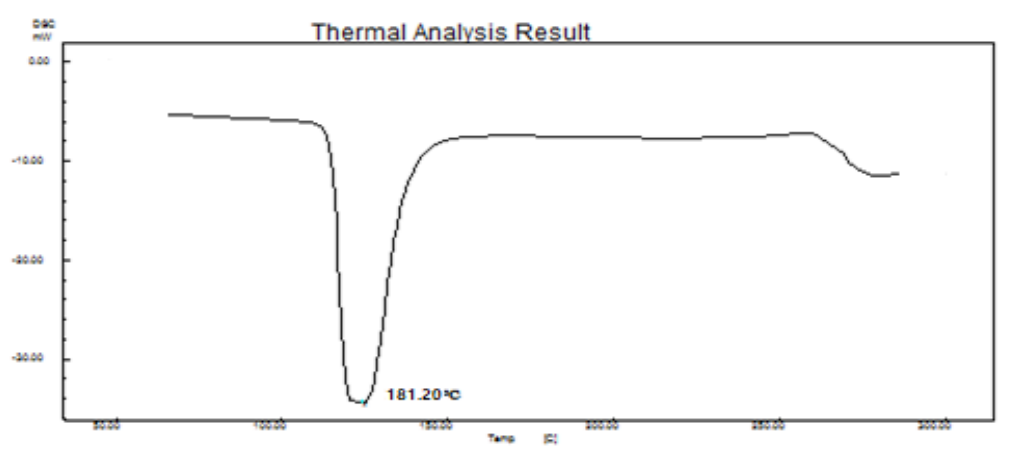

Fig. 6: Thermal analysis result of curcumin

The average melting point of pure drug is $181^{\circ} \mathrm{C}$ which is complies with Stander melting point of drug. From all the FTIR Study and actual perception it was presumed that there was no huge Drug-excipients collaboration was noticed. The consequences of FTIR study shown that there is no adjustment of medication's liquefying top. So we can reason that medication and other excipients are viable which one another.

\section{Calibration curve of curcumin in 6.8 phosphate buffer}

Phosphate buffer $\mathrm{pH} 6.8$ was used for the preparation of curcumin concentration and absorption was measure by Shimadzu UV-1601 UV/Vis double beam spectrophotometer. The $\lambda$ max of curcumin was found to be $424 \mathrm{~nm}$.

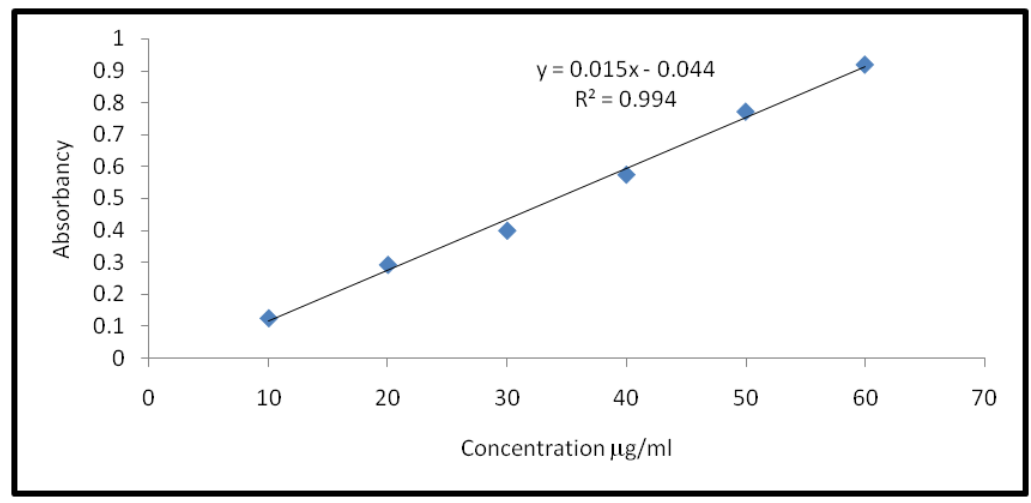

Fig. 7: Drug calibration curve in Phosphate buffer pH6.8

\section{Solubility study}

Solubility studies were carried out by each adding excess of drug in screw-capped vials each containing $50 \mathrm{ml}$ different solubility medium such as water, $1.2 \mathrm{pH}$ buffer, $3.0 \mathrm{pH}$ buffer, $6.8 \mathrm{pH}$ buffer, $7.4 \mathrm{pH}$ buffer. The suspensions were continuously stirred on electromagnetic stirrer (Remi, India) at $37 \pm 0.5{ }^{\circ} \mathrm{C}$ and $300 \mathrm{rpm}$ for three hours. The suspensions were filtered through $0.22 \mathrm{fm}$ membrane filter. The filtrates were suitably diluted and analyzed, spectrophotometrically (Shimazdu-1700, UV/Visible spectrophotometer), for the dissolved drug at $424 \mathrm{~nm}$.

Table 5: Solubility data of curcumin

\begin{tabular}{ll}
\hline Medium & Solubility $\mathbf{( m g / 5 0 ~} \mathbf{~ m l})$ \\
\hline Distilled Water & $235 \pm 0.5$ \\
1.2 pH buffer & $224 \pm 0.5$ \\
3.0 pH buffer & $180 \pm 0.5$ \\
6.8 pH buffer & $236 \pm 0.5$ \\
7.4 pH buffer & $241 \pm 0.5$ \\
\hline
\end{tabular}

Where $\mathrm{n}=3$, mean \pm SEM

\section{Preparation of nanosponge}

\section{Shape analysis}

The shape analysis of the nanosponge, drug loaded nanosponge and $\mathrm{CD}$ conjugates nanosponge obtained is shown in figure. It was evident from SEM photo micrographs that nanosponge, drug loaded nanosponge and CD conjugates nanosponge were discrete, spherical or oval curcumin slightly rough surface. No significant change of shape was found in drug loaded nanosponge and CD conjugates nanosponge as compare to nanosponge.

\section{Aspect ratio}

Aspect ratio was done for the nanosponge's spherocity, for the stream property. Hot stage magnifying instrument was utilized for the estimation of the stature and width of the nanosponge Aspect proportion was determined from following equation:

$$
\frac{\text { Length of nanosponge }}{\text { Width of nanosponge }}=\text { Aspect ratio }
$$

Aspect ratio should be very near to 1 for the best spherical shape.

Table 6: Aspect ratio of different batches

\begin{tabular}{llll}
\hline S. No. & Length (nm) & Width (nm) & Aspect Ratio \\
\hline 1 & $1420.0 \pm 0.05$ & $1368.0 \pm 0.05$ & $1.037 \pm 0.05$ \\
\hline
\end{tabular}

From the above result aspect ratio of the nanosponge is 1.037 .

\section{Scanning electron microscopy}

These studies were done for the nanosponge's shape and surface study. Following study gives perfect idea about shape and surface of the nanosponge prepared. 


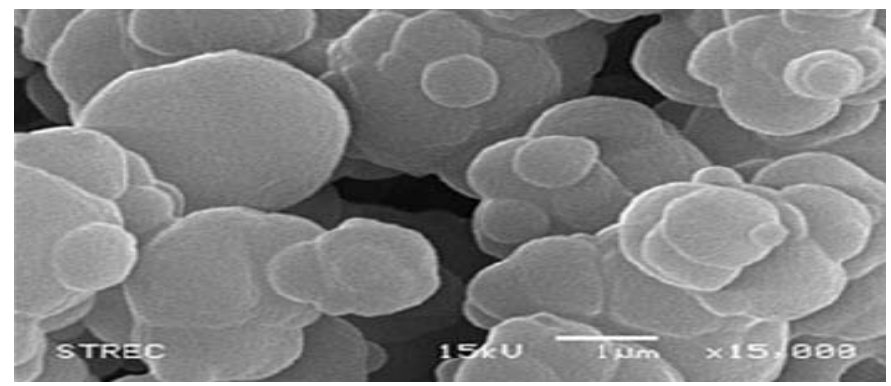

(A)

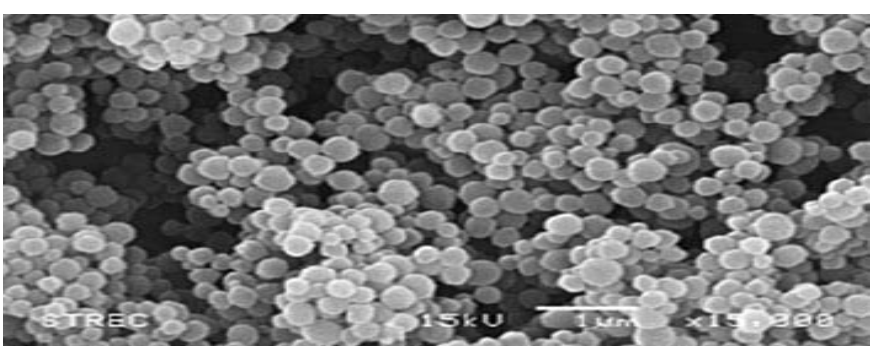

(B)

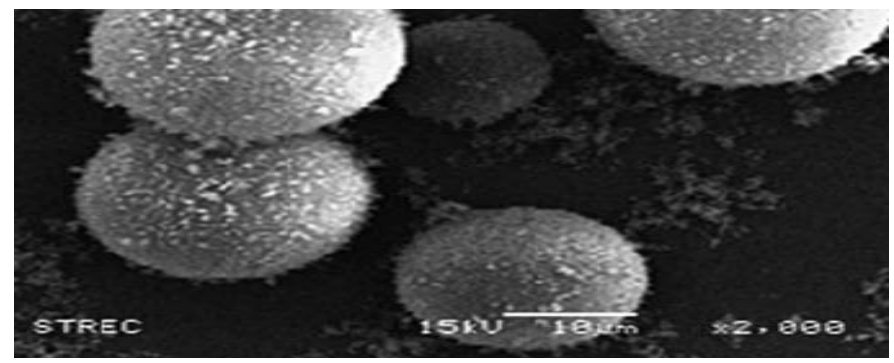

(C)

Fig. 8: Scanning electron micrographs of (A) Nanosponge (B) Drug loaded nanosponge and (C) CD-conjugates nanosponge
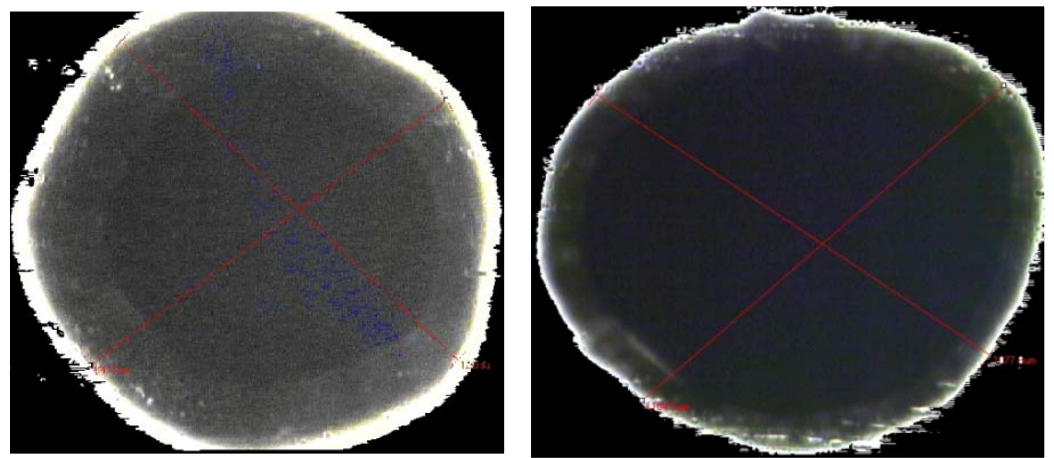

Fig. 9: Aspect ratio of different batches of nanosponge

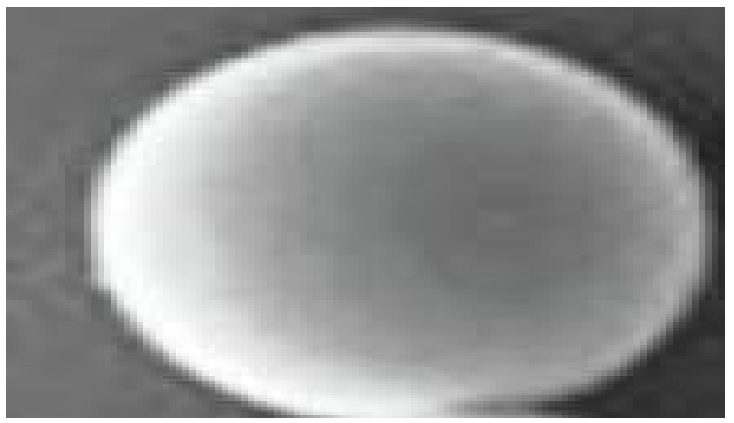

Fig. 10: Scanning electron micrographs of shape and surface size of nanosponge 

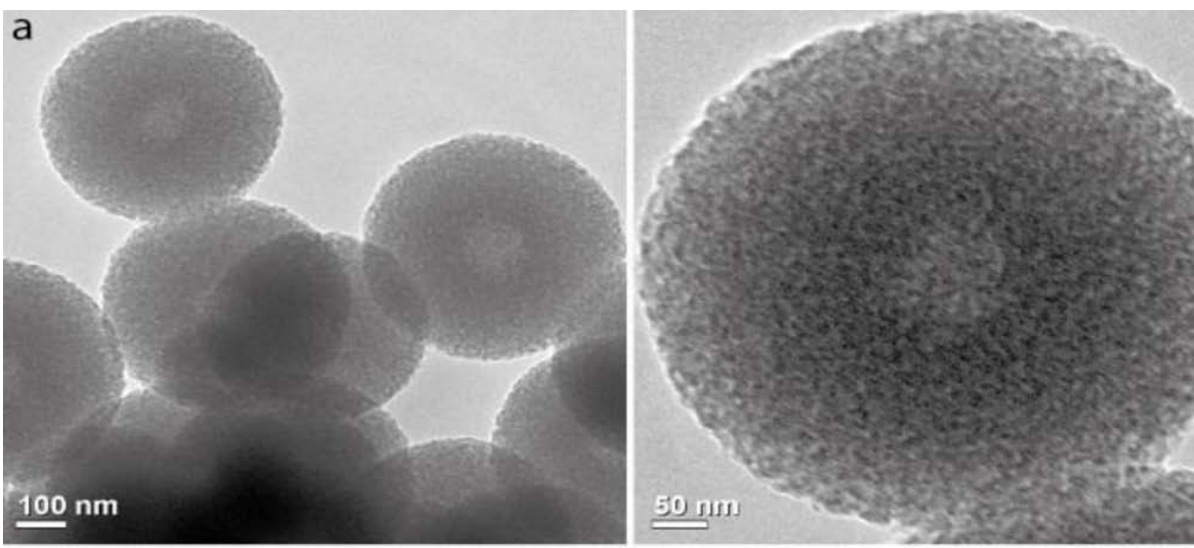

Fig. 11: Transmission electron microscopic images (TEM) at different magnifications (a,b-CUR-CDNS)

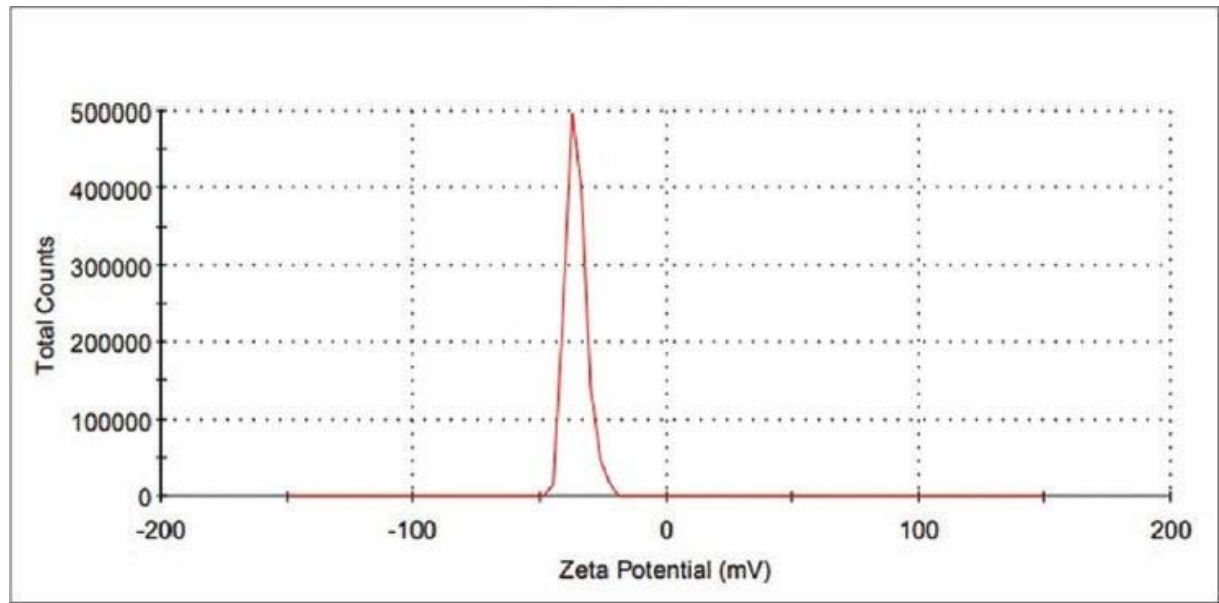

Fig. 12: Zeta potential distribution of curcumin nanosponge, ${ }^{*}$ Values are expressed in $\mathrm{mV}$ where $\mathrm{n}=5$, $\operatorname{mean} \pm \mathrm{SEM}-20.1 \pm 1.57$

\section{Zeta potential}

Particle size analysis exhibits that CUR-CDNS is nanosized with size ranging between 450 and $550 \mathrm{~nm}$ having unimodal distribution exhibiting good homogeneity. Zeta potential noticed for CUR-CD-NS were more negative contrasted with separate plain CUR $(-20.1 \pm 1.57)$ demonstrating solidness of the nanodispersion. The nanochannels shaped in CDNS due to crosslinking of CD outcomes in the permeable design which gives various cooperation destinations notwithstanding the hydrophobic cyclodextrin cavities. These nanocavities help in more noteworthy entanglement of curcumin in CDNS.

\section{In vitro release profile of curcumin}

In vitro profile exhibits the release pattern of curcumin from CURCDNS in comparison with the plain CUR. Plain curcumin showed a lag phase of 3-4 $\mathrm{h}$ while the previous delivery was seen from CURCDNS. The arrival of curcumin from CUR-CDNS at every hour was fundamentally more noteworthy than their separate plain CUR $(P<0.001)$. Curcumin discharge was upgraded to very nearly 10 folds toward the finish of eighth hour. Hydrophilic property of the CDNS and the expanding capacity of pyromellitic dianhydride cross-linked cyclodextrin and nanoscale molecule size helps in wetting, solubilization bringing about quicker and improved delivery from CUR-CDNS. For the comparison purpose nanosponges are betacyclodextrins crosslinked with carbonate bonds. The polymer formed is nanoparticulate in nature, that the solubility of itraconazole was enhanced more than 50 -folds with a ternary solid dispersion system [27] but present work increased solubility as well as also increased the drug release profile of poorly water soluble drugs. They offer unique advantage of controlled release and are biologically safe.

\section{In vitro cytotoxicity activity}

Cytotoxicity and synergism CUR-CDNS showed a dose-dependent effect on MCF-7 cell proliferation analyzed by MTT method. In vitro cell culture toxicity assays were carried out on different cell lines (i.e., HELA; MCF7, COS) by using the MTT test. Cells were incubated for between 24 and $72 \mathrm{~h}$ and their viability determined. After incubation with nanosponges no cytotoxicity was observed [27]. Mix of CURCDNS at 3:1 proportion displayed a huge expansion in cytotoxicity impact in a fixation subordinate way $\left({ }^{*} \mathrm{P}<0.05\right)$ when contrasted and the single treatment of CUR-CDNS. Development hindrance of the cells at 1:3 mix proportions was not essentially unique in relation to CUR-CDNS single treatment at all fixations and like 1:1 mix proportion at a lower focus. Notwithstanding, the two blends $(1: 3$ and $1: 1$ proportion) showed a critical contrast $(* \mathrm{P}<0.01)$ against. Clear nanosponges didn't show any cytotoxic impact on cell societies. The IC ${ }_{50}$ worth of CUR-CDNS was seen to be $10.11 \mu \mathrm{g} / \mathrm{ml}$ $(n=3)$. Treatment with a combination of CUR-CDNS at 1:1 and 1:3 ratios resulted in an $\mathrm{IC}_{50}$ value of $14.98 \mu \mathrm{g} / \mathrm{ml}$. Other in vitro methods for evaluating the toxicity of new materials include the determination of its haemolytic properties. When nanosponges were incubated with human erythrocytes for $90 \mathrm{~min}$, no haemolytic activity was observed up to a concentration of $15 \mathrm{mg} / \mathrm{ml}$, showing that the nanosponges possess good blood compatibility [27]. So the Cyclodextrin-based nanosponges were found better compatibility and stability for in vitro cytotoxicity method. 
Characterization based stability study of CUR-CD-NS
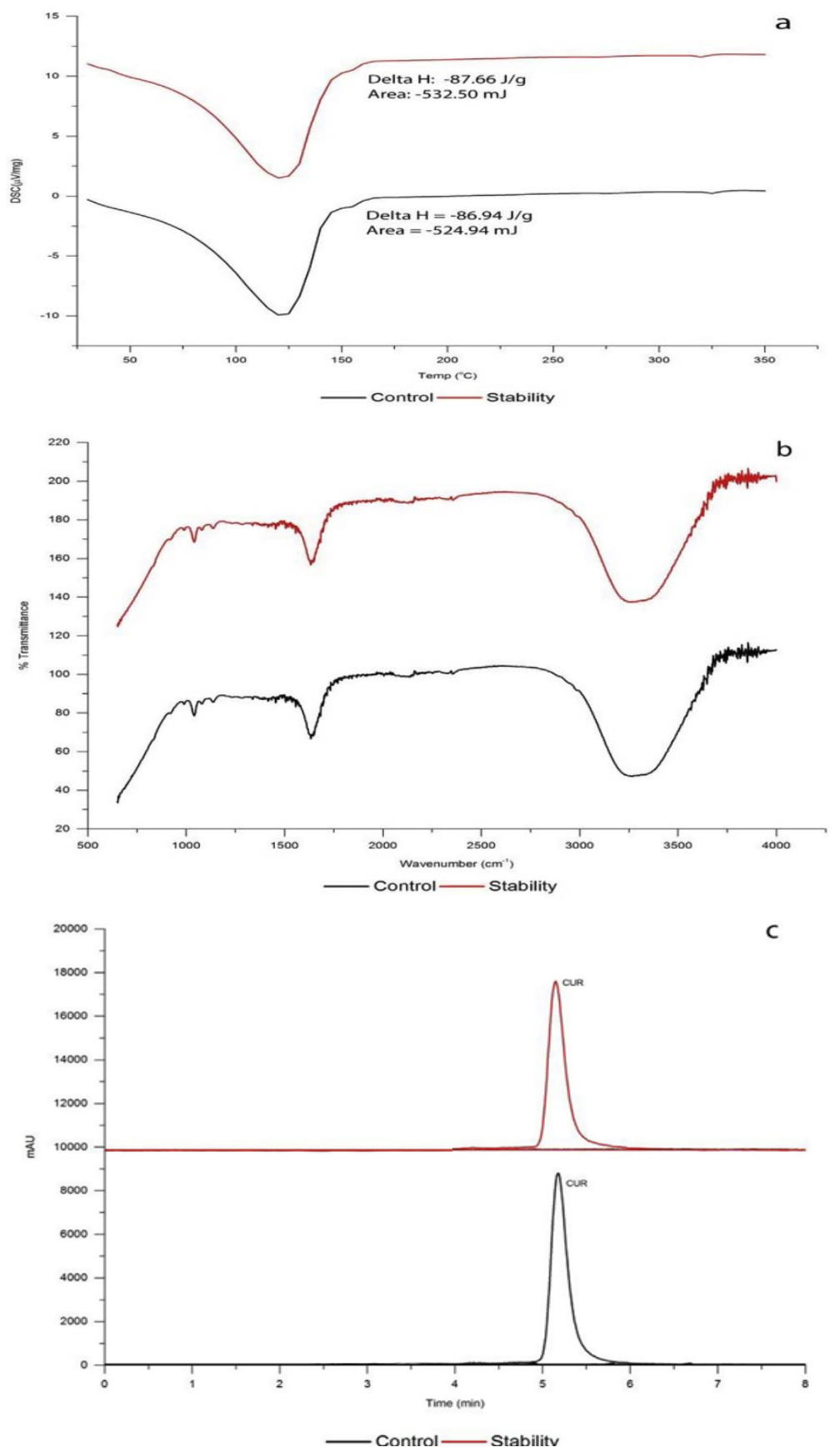

Fig.13: Characterization graphs of formulation-control $\left(* 25^{\circ} \mathrm{C} \pm 2{ }^{\circ} \mathrm{C}\right)$ and stability $\left(8 \mathrm{w}\right.$ at $\left.* 40{ }^{\circ} \mathrm{C} \pm 2{ }^{\circ} \mathrm{C}\right)$ a-Differential scanning calorimetric thermograms (DSC); b-Fourier transform Infra-red spectra (FTIR); C-HPLC peaks

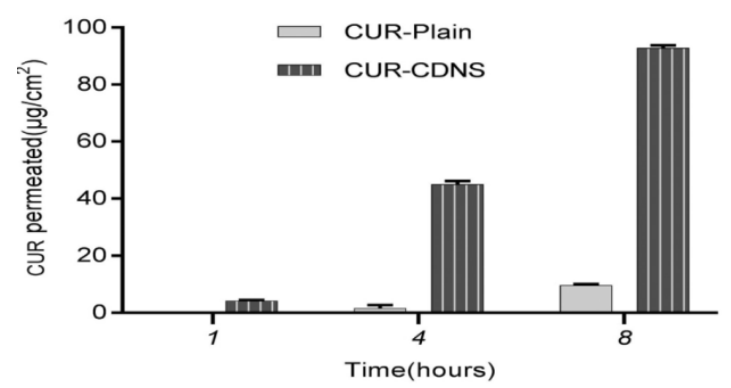

Fig. 14: \% drug release, $*$ Values are expressed in hours where $\mathrm{n}=3$ mean $\pm \mathrm{SD},(\mathrm{P}<0.001) * \mathrm{P}<0.01$ to $* \mathrm{P}<0.05$

\section{CONCLUSION}

Cyclodextrin nanosponges (CDNS) were fabricated using pyromelliticdianhydride as a crosslinker and loaded with curcumin. These nanosized curcumin nanosponges (CUR-CDNS) showed greater in vitro release than respective plain curcumin. In vitro cytotoxicity study and combination index analysis showed the synergistic effect of CUR-CDNS against MCF-7 cells. The present study reveals that the combination of curcumin results in higher cytotoxicity against breast cancer cells and suggests cyclodextrin nanosponges as an effective nanocarrier for the delivery of curcumin.

\section{FUNDING}

None 


\section{AUTHORS CONTRIBUTIONS}

All the authors have equally contributed to this manuscript.

\section{CONFLICT OF INTERESTS}

The authors declare no conflict of interest, financial or otherwise.

\section{REFERENCES}

1. Priyadarsini KI. The chemistry of curcumin: from extraction to therapeutic agent. Molecules. 2014 Dec;19(12):20091-112. doi: 10.3390 /molecules191220091, PMID 25470276.

2. Gupta SC, Sung B, Kim JH, Prasad S, Li S, Aggarwal BB. Multitargeting by turmeric, the golden spice: from kitchen to clinic. Mol Nutr Food Res. 2013 Sep;57(9):1510-28. doi: 10.1002/mnfr.201100741, PMID 22887802.

3. Unlu A, Nayir E, Dogukan Kalenderoglu MD, Kirca O, Ozdogan M. Curcumin (Turmeric) and cancer. J Buon. 2016 Sep 1;21(5):1050-60. PMID 27837604.

4. Lüer SC, Goette J, Troller R, Aebi C. Synthetic versus natural curcumin: bioequivalence in an in vitro oral mucositis model. BMC Complement Altern Med. 2014 Dec;14(1):53. doi: 10.1186/1472-6882-14-53, PMID 24517289.

5. Singh S. From exotic spice to modern drug? Cell. 2007 Sep 7;130(5):765-8. doi: 10.1016/j.cell.2007.08.024, PMID 17803897.

6. Hatcher H, Planalp R, Cho J, Torti FM, Torti SV. Curcumin: from ancient medicine to current clinical trials. Cell Mol Life Sci. 2008 Jun;65(11):1631-52. doi: 10.1007/s00018-008-7452-4, PMID 18324353.

7. Qin F, Huang X, Zhang HM, Ren P. Pharmacokinetic comparison of puerarin after oral administration of Jiawei-Xiaoyao-San to healthy volunteers and patients with functional dyspepsia: influence of disease state. J Pharm Pharmacol. 2009 Jan;61(1):125-9. doi: 10.1211/jpp/61.01.0018, PMID 19126307.

8. Zhou H, Beevers CS, Huang S. The targets of curcumin. Curr Drug Targets. 2011 Mar 1;12(3):332-47. doi: 10.2174/138945011794815356, PMID 20955148.

9. Prasad S, Gupta SC, Tyagi AK, Aggarwal BB. Curcumin, a component of golden spice: from bedside to bench and back. Biotechnol Adv. 2014 Nov 1;32(6):1053-64. doi: 10.1016/j.biotechadv.2014.04.004, PMID 24793420.

10. Kocaadam B, Sanlier N. Curcumin, an active component of turmeric (Curcuma longa), and its effects on health. Crit Rev Food Sci Nutr. 2017 Sep 2;57(13):2889-95. doi: 10.1080/10408398.2015.1077195, PMID 26528921.

11. Zhu L, Ding X, Zhang D, Yuan Ch, Wang J, Ndegwa E, Zhu G. Curcumin inhibits bovine herpesvirus type 1 entry into MDBK cells. Acta Virol. 2015 Sep 1, Ch Y;59(3):221-7. doi: 10.4149/av_2015_03_221, PMID 26435144.

12. Baglole KN, Boland PG, Wagner BD. Fluorescence enhancement of curcumin upon inclusion into parent and modified cyclodextrins. J Photochem Photobiol A. 2005 Jul 15;173(3):230-7. doi: 10.1016/j.jphotochem.2005.04.002.

13. Tønnesen HH. Solubility, chemical and photochemical stability of curcumin in surfactant solutions. Studies of curcumin and curcuminoids, XXVIII. Pharmazie. 2002 Dec 1;57(12):820-4. PMID 12561244.
14. Kim TH, Jiang HH, Youn YS, Park CW, Tak KK, Lee S, Kim H, Jon $S$, Chen X, Lee KC. Preparation and characterization of watersoluble albumin-bound curcumin nanoparticles with improved antitumor activity. Int J Pharm. 2011 Jan 17;403(1-2):285-91. doi: 10.1016/j.ijpharm.2010.10.041, PMID 21035530.

15. Manju S, Sreenivasan K. Conjugation of curcumin onto hyaluronic acid enhances its aqueous solubility and stability. J Colloid Interface Sci. 2011 Jul 1;359(1):318-25. doi: 10.1016/j.jcis.2011.03.071, PMID 21492865.

16. Mohanty C, Sahoo SK. The in vitro stability and in vivo pharmacokinetics of curcumin prepared as an aqueous nanoparticulate formulation. Biomaterials. 2010 Sep 1;31(25):6597-611. doi: 10.1016/j.biomaterials.2010.04.062, PMID 20553984.

17. Anitha A, Maya S, Deepa N, Chennazhi KP, Nair SV, Tamura H, Jayakumar R. Efficient water soluble O-carboxymethyl chitosan nanocarrier for the delivery of curcumin to cancer cells. Carbohydr Polym. 2011 Jan 10;83(2):452-61. doi: 10.1016/j.carbpol.2010.08.008.

18. Dhule SS, Penfornis P, Frazier T, Walker R, Feldman J, Tan G, He J, Alb A, John V, Pochampally R. Curcumin-loaded $\gamma$ cyclodextrin liposomal nanoparticles as delivery vehicles for osteosarcoma. Nanomedicine. 2012 May 1;8(4):440-51. doi: 10.1016/j.nano.2011.07.011, PMID 21839055.

19. Byrne JD, Betancourt T, Brannon-Peppas L. Active targeting schemes for nanoparticle systems in cancer therapeutics. Adv Drug Deliv Rev. 2008 Dec 14;60(15):1615-26. doi: 10.1016/j.addr.2008.08.005, PMID 18840489.

20. Yadav VR, Suresh S, Devi K, Yadav S. Effect of cyclodextrincomplexation of curcumin on its solubility and antiangiogenic and anti-inflammatory activity in rat colitis model. AAPS PharmSciTech. 2009 Sep;10(3):752-62. doi: 10.1208/s12249-009-9264-8, PMID 19495987.

21. Swaminathan S, Vavia PR, Trotta F, Torne S. Formulation of betacyclodextrin based nanosponges of itraconazole. J Incl Phenom Macrocycl Chem. 2007 Apr;57(1-4):89-94. doi: 10.1007/s10847-006-9216-9.

22. Cavalli R, Trotta F, Tumiatti W. Cyclodextrin-based nanosponges for drug delivery. J Incl Phenom Macrocycl Chem. 2006 Oct;56(1-2):209-13. doi: 10.1007/s10847-006-9085-2.

23. Torne SJ, Ansari KA, Vavia PR, Trotta F, Cavalli R. Enhanced oral paclitaxel bioavailability after administration of paclitaxelloaded nanosponges. Drug Deliv. 2010 Aug 1;17(6):419-25. doi: 10.3109/10717541003777233, PMID 20429848.

24. Shikha S, Priyanka C, Surendra KJ. Development and performance evaluation of tumor targeting potential of folate spacer functionalized solid lipid nanoparticles, Asian. J Pharmaceuitcaland Clin Res. 2021 Sep 14;6:1-7.

25. Hirlekar RS, Kadam VJ. Design of buccal drug delivery system for a poorly soluble drug. Asian J Pharm Clin Res. 2009 Jul;2(3):49-53.

26. Bhanja S, Ellaiah $P$, Chandan $M$, Murthy KV, Bibhutibhusan $P$, Kumar PS. Design and in vitro evaluation of mucoadhesivebuccal tablets of perindopril prepared by sintering technique. Int J Pharm Tech Res. 2010;2(3):1810-23.

27. Trotta F, Zanetti M, Cavalli R. Cyclodextrin-based nanosponges as drug carriers. Beilstein J Org Chem. 2012;8(1):2091-9. doi: 10.3762/bjoc.8.235, PMID 23243470. 